\title{
New approaches to sustainable rural development: Social farming as an opportunity in Europe?
}

\author{
Antoni F. Tulla*, Ana Vera, Natàlia Valldeperas, Carles Guirado
}

Universitat Autònoma de Barcelona, Spain

The so-called "Green Revolution" has marginalized and depopulated many rural areas, but economic diversification has emerged since the 1980s. Consumer appreciation for organic farming and proximity sourcing has increased, and farmers have responded to this market. Since 2008 the economic crisis has led to importation of low-quality food products at an unsustainable level of energy costs, and the lack of employment opportunity has led people to seek economic opportunities in the countryside, producing foods with ecological criteria for short food supply chains. Within this scenario, Social Farming (SF) has appeared as a multifunctional innovative strategy. It gives a return to society through the production and processing of agricultural products by incorporating direct social benefits in employment, training, and therapy or rehabilitation of groups at risk of social exclusion. SF offers social cohesion, empowerment of vulnerable groups, local development in rural and peri-urban settings, and an equitable balance between revenues and costs to society.

Key Words: added-value products, Catalonia, Europe, multifunctionality, risk of social exclusion, social farming, sustainable rural development.

Article Info: Received: March 29, 2017; Revised: April 15, 2017; Accepted: May 16, 2017; Online: May 25, 2017.

\section{Introduction}

Commercial agriculture seeks to maximize production efficiency leading to profound changes in farms and rural areas throughout Europe. The intensive farming of the so-called "Green Revolution" has marginalized many agricultural areas, which have become depopulated. Economic diversification in rural areas since the 1980s, incorporating tourism activities and generating added value in

\section{* Corresponding author}

Address: Universitat Autònoma de Barcelona, Department of Geography, Building B, 08193, Bellaterra, Spain.

Phone: +34935811527 | Email: antoni.tulla@uab.cat

(C)2017 Human Geographies; The authors

(c) (i) This work is licensed under a

Creative Commons Attribution 4.0 International License. DOI:10.5719/hgeo.2017.111.2 
agricultural products, has driven a shift to the present multifunctionality. At the same time, consumer appreciation for organic farming and proximity sourcing has increased, and farmers have responded to this market.

Since 2008, the global crisis has aggravated the economic situation of a large part of the population. On one hand, more and more low-quality food products are imported, at an unsustainable level of energy costs. On the other hand, the lack of employment opportunity has led many people to seek economic opportunities in the countryside; producing new products based on ecological criteria and marketed in short food supply chains.

Within this scenario, Social Farming (SF) has appeared in several European countries in different forms. Through production and processing of agricultural products that incorporates direct social benefits in employment, training, therapy or rehabilitation of groups at risk of social exclusion, SF gives society a return on public and private investment in the form of social contributions, especially in four areas: a) social cohesion; b) empowerment of socially vulnerable groups; c) local development in rural and peri-urban settings; and d) an equitable balance between revenues and costs to society. We will discuss this emerging activity as an innovative instrument within the framework of agricultural and rural multifunctionality, defining SF, outlining its main features and its dissemination throughout Europe, and highlighting some specific examples in the Catalan context.

\section{Objectives and methodology}

The objective of this research was to evaluate how new activities such as SF can help to develop rural areas in a sustainable way. We present some general ideas about rural development today, review comparative advantage theories, discuss the SF concept and various approaches in Europe, and assess which contributions of SF could promote sustainable rural development (SRD).

The methodology consisted of five elements: (1) a review of literature on social economy, rural development, the welfare state system, and SF; (2) indepth interviews about some rural experiences of comparative advantage in the Catalan Pyrenees, (3) interviews at several SF projects in Catalonia, (4) creation of an database of currently active SF projects in Catalonia, and (5) economic viability (CANVAS method) and social return on investment (SROI) analysis applied to selected SF projects in Catalonia.

Rural development, sustainability, and resilience

A multifunctional countryside means that rural activity can obtain multiple results, not only with the production of goods and raw materials but also with value-added agro-food, tourism, and environmental and social benefits (Potter, 2004).

Agriculture can also contribute to the sustainability of the rural landscape, the protection of biodiversity, the creation of jobs along with the diversification of agro-industrial activities and services, and therefore contributes to the viability of rural areas. 
This new situation has been called "the commodification of the countryside" (Best, 1989), in which consumers, who mainly live in cities, are prepared to pay more for the value of certain goods. A simple example is a cost comparison of farmland, where the price is based on its production value, with land occupied by second homes or tourism-related activities, where the price depends on what the consumer is willing to pay (Tulla et al., 2009). Agrarian use can be priced out of the market. In this sense, we often talk about a double market for a piece of land, depending on what it will be used for.

The only solution is that territories implement planning policies for the activities and land use as required, thereby avoiding this double market. Some traditionally rural activities such as cycling, fishing, horseback riding, boating, and hiking have become experiences to sell to tourists, often with the addition of new technologies (Perkins, 2006).

The nature of Rural Development (RD) requires a dual approach: integrative and cross-cutting. It deals with all dimensions of the rural world (economic specialization, cultural heritage, social and human capital, and the environment), but at the same time focusses on the social and economic welfare of the population, which is measured more by the quality of life in the countryside than the GDP of the area (Ploeg et al., 2000). RD aims at improving rural people's livelihoods in an equitable and sustainable manner, both socially and environmentally, through better access to assets (natural, physical, human, technological, and social capital) and services and better control over their productive capital (in its financial or economic and political forms), which enables them to improve their livelihoods on a sustainable and equitable basis (Atchoarena et al., 2003).

RD has to combine economic, social, and environmental policies with the idea that resources must be available for future generations. In this sense, there is an opposition between growth, understood simply as an economic increase, and sustainable development that considers quality of life, appropriate use of resources, and environmental protection more important than GDP. "Sustainable development" is a concept formulated by the Bruntland Commission (UN General Assembly, 1987), in which development to satisfy present needs of the population will not compromise resources needed for future generations. If we consider that RD must be sustainable, then we must accept that policies and actions to develop a territory must take into account the need to avoid using up available resources.

Since 1989, structural funds for rural regions from the European Union (EU), defined in the Community Agrarian Policies (CAP), have had three main aims: To compensate spatial imbalance (access to economic and social opportunities), to correct socioeconomic inequalities (e.g., gender- and age-related differences), and to promote environmental protection and gradual implementation of sustainable policies (Esparcia, 2000). In practice, this means "introducing new Sustainable Rural Development (SRD) policies". For example, the methodology of the LEADER Programme is described as follows:

(a) Spatial design in opposition to sectorial approaches in rural policies; (b) Bottom-up decision making opposite to Up-down (sic) political and economic decisions; (c) Integrative and participative system of actors and institutions of a territory, being set up the 'Local Action Groups' (LAG) to coordinate these 
policies and actions; (d) Innovative actions to promote SRD like organic food, agro-eco-energy, or Alps energy wood, with scientific and technical support and public and private finances; (e) Global analysis of problems and opportunities in a multi-sectorial approach; (f) Decentralize financial support through cooperatives, ethic banks and local management; and (g) A network organization of projects, their actors and institutions involved.

The notion of resilience has begun to appear in social and environmental sciences as the capacity of a social-ecological system to absorb disturbance and reorganize while being subjected to the forces of change, being able to keep the bulk of its functions, structure, identity, and feed-backs intact (Exterckoter et al., 2015). This new concept has the potential for use in RD, which has been trying since the 1960s to resolve at least three problems: to find an economic base for rural areas, to achieve a quality of life for their population that takes environmental matters into consideration, and to organize local rural society within the framework of a globalized world (Halfacree, 2007).

Resilience is a dynamic social process, determined partially by the ability of communities to act collectively and solve common problems. One of the key elements for $\mathrm{RD}$ is the integration of foreigners and their proposals into the local activity, and that the original population accepts them as ordinary members of the community (Halfacree, 2007). Economic cycles and crises are part of the daily life of rural communities. Farmers have always had to find solutions to address unexpected events related to the environment (hail, frost, drought), as well as economic and market uncertainty. However, increased competition, globalization, and environmental changes have increasingly demanded more adaptive responses from family farmers.

\section{Comparative advantage in rural areas}

Territorial planning and management in rural areas seeks to identify a territory's problems and, at the same time, to seek out activities that will promote SRD. The theory of comparative advantage (Tulla et al., 2009) is an important tool to assess a region's options based on certain products or services. This is the case in some mountainous areas where the processing and marketing of dairy products generates added value with quality products that have proven to be competitive and at the same time contribute to the preservation of territorial and environmental quality. For example, the Cadí Cooperative, founded in 1915 by dairy farmers, has a processing plant that produces high-quality value- added products (cheese and butter), that has achieved a "designation of origin" status. It currently exports $50 \%$ of its production output and for 50 years has managed to offer farmers milk prices more than $20 \%$ above the average price per kilo paid in Spain and France (Pallarès-Blanch et al., 2015). In addition, the Pirenaica Producers' Cooperative uses a "just in time" system that has helped to reduce costs, around $15 \%$ per year in relation to average agricultural costs in Spain, while obtaining quality feed adapted to the needs of each farm (Tulla et al., 2009).

The comparative advantage in mountain areas, a periphery in regional development models (Vera et al., 2011), can be explained through a reinterpretation of the classic economic principle of comparative advantage (Tulla, AF et 
al., 2009). The old-school approach tells us that each country will specialize in those goods and services that it produces under better conditions, rather than producing all the goods and services that the country needs. For Ricardo (1817), author of the theory of comparative costs between different regions, the advantages are based on the natural or historical conditions available to produce goods, which implies considering the differential incomes that can be produced in relation to the quality of the soil or other natural resources. Von Thünen (1826) incorporates the costs of transportation, because its location, into the previous analysis, assuming a homogeneous territory.

Heckscher-Ohlin (Ohlin, 1933) emphasized the characteristics of the factors of production in each region. In this analysis, a territory will export more goods and services that require intensive use of factors with which it is well endowed, and will import those goods and services that require intensive use of factors not available in a given territory. This assigns value to a country's level of technology and its knowledge base, introducing the consideration of added value. It was Olsen (1971) who first argued that each region has a relative advantage, within the framework of comparative advantage, which can be measured as the opportunity cost of not specializing in the production of goods and services for which a given region is best equipped or well supplied. The centre-periphery theory, developed by Myrdal (1957), posits that uneven development increases with increasing negative economies diseconomies. Developed regions generate negative effects due to excessive growth and congestion. Thus, peripheral regions have the opportunity to locate economic activities with comparative advantage in a network of innovative small and medium-sized enterprises (Pallarès-Barberà et al., 2004). According to Peet and Hartwick (1999), development models are moving away from simple large-scale economic growth to prioritize small enterprises, in peripheral areas, that are based on value-added activities, respecting the environment and landscape.

In order to identify new opportunities for sustainable development of peripheral regions, we must determine which activities are more appropriate in each place. In the case of the Pyrenees, we propose four vectors: 1) high-quality, value-added goods and services, 2) sustainable use of natural resources and landscape, 3) a reliance on the human and territorial base that facilitates naturbanization, and 4) maximization of the innovative energy of women's entrepreneurship. We also apply the concept of the second-best option (SBO), from the Theory of Second Best, the point in "Pareto optimality" at which only one of the necessary conditions is missing (Lipsey et al., 1956). Our study is based on the idea of lacking a condition for regional development in a peripheral area. We did not undertake an econometric analysis, instead developing a qualitative analysis involving in-depth interviews and focus groups (PallarèsBlanch et al., 2014).

From another point of view, each local territory may develop an activity or offer a service that remains the best possible area of specialization for that territory even if other places may be "best" suited for it. The existence of a territory itself as the "SBO" to carry out one or more economic activities allows the reformulation of rural development policies with a focus on sustainability (Tulla et al., 2009). Examples include the transformation of milk into valueadded products, non-profit organizations developing rural tourism, activities 
using information and communication technologies, extensive livestock production with autonomous resources such as vaccine breeds, in the high Pyrenees and Aran (APiA) and in other territories that seek to establish and promote an identity (Vera et al., 2011, Barrachina et al., 2015).

It is also important to take into account the concept of territorial embeddedness to explain local development. This approach emphasizes the network of institutions and socio-cultural elements that allow the development of strategies that foster loyalty to a given territory among both producers and consumers. It promotes a dynamic incorporation of small and medium enterprisers (SME) in a given area, where institutions and local networks of economic activity and social collectives generate an economic space that constitutes a favourable foundation for industrial enterprises. A 'territorial cluster' develops in which internal economic and social relationships are preferred over certain external ones (Pallarès-Barberà et al., 2004).

\section{Concept and characteristics of Social Farming}

Social Farming (SF) includes those activities using agricultural resources to promote health and generate therapeutic services, rehabilitation, inclusion, education and training, and employment, mainly in rural and peri-urban areas (Di Iacovo et al., 2009). In SF projects, agricultural activity, social care and social policies come together to provide innovative solutions to the situation of diverse groups at risk of social exclusion (RSE) and promotes local development in rural and peri-urban areas. There are two main studies on SF in Europe: (A) Social Services in Multifunctional Farms: 'Social Farming' (2005 and 2008) ${ }^{1}$ and (B) Green Care, COST 866 (Sempik et al., 2010).

The diverse elements of SF can be presented in six categories:

(1) Activity, which includes agrarian products and their transformation, distribution and catering, rural services, and the attraction of nature and rural landscape environment;

(2) Objectives, such as the integration of persons and groups at risk of social exclusion, achieving health benefits, or/and receiving income from having a job, and participants being empowered to trust themselves;

(3) Population, reflecting the diverse RSE groups served: people with mental, physical or psychological disability, social and economic integration difficulties and at risk of poverty (structural unemployment, drugs and other addictions, prisoners, immigrants, etc.), and young people with learning difficulties or older people with low income or social needs;

(4) Resources, including health and therapeutic services, jobs in agrarian farms, access to land and buildings, local government support and other public financing (funds, subsidies for social security costs, and so on) and funding and social support provided by foundations, charities, associations, and other Third Social Sector (TSS) entities, among others;

(5) Legal status and management of SF projects, such as non-profit private company, public administration (basically at a local level), and TSS cooperatives, associations, and foundations, and (specifically in Catalonia) four formal modalities of inclusion (Insertion company, Occupational centre, Association, and Special Centre of Work); 
and (6) Links with and between institutions, including networks to support the creation and consolidation of SF (e.g., Xarxa Agrosocial ${ }^{2}$ in Catalonia) and diverse forms of collaboration among SF projects (assessment, trade, sharing resources, and so on).

Access to land is very complicated and varies by country. Organizations such as "Terra Franca" in Catalonia", "Terre de Liens" in France 4 , "Soil Association Land Trust" in the United Kingdom", or "Regionalwert AG" in Germany", among others, facilitate contacts between SF projects and people interested in selling land, but may also rent or purchase land for young farmers or SF projects. Institutional and financial systems related to SF also vary by country. In Italy, one of the pioneers when SF began in the 1970s, we found non-profit organizations, social cooperatives, private initiatives, and volunteer organizations that actively support public or private initiatives. In the past decade, there were 6,000 social cooperatives and 190,000 employees. In August 2015, the Italian Parliament approved a specific law on SF that takes into account all the related structural elements ${ }^{7}$. In France, Les Jardins de Cocogne ${ }^{8}$ is a TSS network of 120 SF community vegetable gardens and other networks developed by agrarian organizations ${ }^{9}$ also employ people at RSE.

From a broad perspective, it could be said that there are four SF organizational models in Europe (Tulla et al., 2014):

(A) Social welfare model, northern Europe, based on the fundamental right of all citizens to access health and social services through a national health system. This model is sustained by high incomes taxes and has a dual objective: policies of social integration and policies that provide economic support for the farms.

(B) Corporative model, central Europe, providing parallel (public and private) health and social services. There is a public interest in promoting "care farms" and, thanks to the subsidization policies, many training courses are organized. There is a trend to increase agrarian production activity to be more selfsufficient and less dependent upon public subsidies.

(C) Anglo-Saxon model, United Kingdom, based mainly on assistance to families and individuals with specific needs and difficulties. Services are provided through the TSS, volunteers, and public or church-related charities.

(D) Mixed model, mainly in Mediterranean countries, where a combination of public and private institutions and volunteers (including families) engage in SF activity. The TSS is growing and, in some cases, replacing public health and social services. The role of families has been very important in the early stages.

There are three main approaches to applying nature and agrarian activities to take care of persons at RSE: Green care, Care farming, and Social farming. Green care uses nature-based therapies to improve the conditions of people with disabilities, who are considered users (Dessein et al., 2013).

Care farming is developed in agricultural farms where farmers take care of people at RSE, providing therapy or occupation to clients (Hassink et al., 2006). Social farming pays persons at RSE and considers them as co-workers and/or members of the project (Di Iacovo et al., 2014). These three models have the aim of empowering the entire RSE population, providing appropriate treatment ranging from only health-related users to paid participants with strong involvement in project development. 


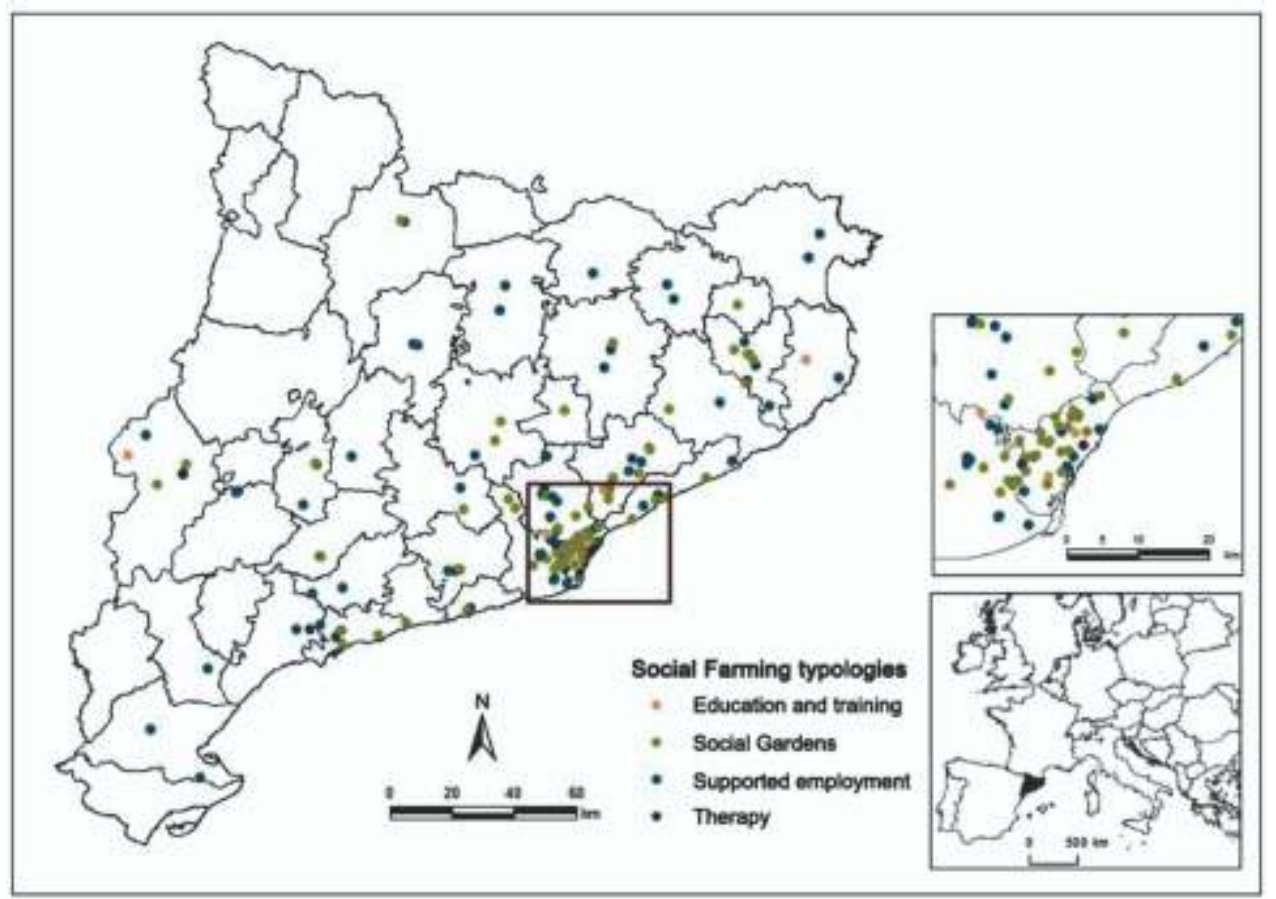

Figure 1. Main typologies and location of SF projects in Catalonia

Sources: Elaboration from own research data

Some results of social farming in Catalonia

Catalonia has 32,108.2 km2 and a total population of 7,508,106 (Idescat, 2016). Of the working population of 3,101,900, just $1.48 \%$ (46,100 people), are employed in the agricultural sector, which has experienced a clear decline in jobs in recent decades (INE, 2016). The utilized agricultural area (UAA) in Catalonia, including pasture and cultivated land, has declined in the last 15 years, from $1,869,203$ ha in 1997 to $1,125,268$ ha in 2013 . The number of farms has also decreased, from 68,944 (1997) to 59,097 in 2013 (Idescat, 2013), with small farms disappearing and large ones increasing in size. However, despite the employment decline in the primary sector, in Catalonia there are emerging projects that focus on agrarian multifunctionality, generating local agroecological projects, social innovations, and the production of quality agro-food products, which share a common denominator: agriculture that is respectful and connected with the territory. Most of the $155 \mathrm{SF}$ entities registered in the database (Figure 1) are part of this set of initiatives that value family farms or small-scale agriculture and short food supply chains.

\section{Some results of social farming in Catalonia}

The main area of SF activity is social and labour-market insertion, generating job opportunities for groups at RSE (47\%) or providing therapy or rehabilitation (4\%) for people with some type of addiction, for example, or education and training (4\%) for young people who have left school prematurely. The second major area is social gardening $(43 \%)$, in response to inequalities and to the social 
emergency caused by the economic crisis that began in 2008. These efforts are driven by social movements, citizen initiatives and/or local governments with the aim of supporting families and individuals in precarious situations.

Each SF experience focuses on one or more socially vulnerable groups. Most are people with disabilities and / or mental disorders (35\%). However, before the crisis of 2008, a much higher proportion of projects focused on social and labour-market insertion or therapy for people with disabilities. In recent years, the socio-economic situation has widened the RSE spectrum, mainly to include people in situations of material deprivation or unemployment, and this has aroused the interest of some promoters of SF initiatives to find solutions to multiple situations of social emergency. At present, $28 \%$ of registered projects receive people living in poverty and $9 \%$ focus on the unemployed. The projects give them job options through agricultural work, or offering them land to grow their own foods. Another important group is the older population (14\%), benefited by the creation and regulation of gardens for retired people, especially in the metropolitan area. Other under-represented and socially vulnerable groups include young people, schoolchildren, people from correctional environments, immigrants, battered women or the homeless (14\%).

Most of these projects are devoted to agriculture (77\%), especially horticulture but also vineyards, olive orchards, and mushroom production, among others. Other initiatives registered as SF are dedicated to agro-food processing $(8 \%)$, such as dairy products (cheeses, yogurts, etc.), jams and preserves, or craft beer. Forestry and forest products represent $8 \%$ of the total, and other entities are engaged in the services sector linked to agricultural activity, such as marketing through short food supply chains (5\%), crafts (1\%) and, lastly, livestock activities (1\%). It is important to note that most of these projects apply ecological criteria to their production activities $(61 \%)$, which seems to be a strength of the sector, due to the importance given to improving the health of the beneficiaries and of the environment.

According to their legal status, TSS entities with a clear social and care function may be classified as non-profits, such as foundations (14\%) or associations $(22 \%)$, or as private institutions (15\%) and cooperatives (12\%) (Laville, 2015). We also find projects of a public nature, driven by local government $(37 \%)$, that have lately had a more proactive role in the implementation and development of SF initiatives at the local level, such as the creation of social gardens. Collaboration between the public and private sectors is often necessary, with the aim of fostering social cohesion, a solidarity economy, and resilient local development.

The development and progressive updating of the database allowed us to analyse the evolution of SF in Catalonia. In the 1970s, the first initiatives appeared as agricultural cooperatives, such as l'Olivera ${ }^{10}$ and La Fageda ${ }^{11}$, which would launch a growing sector - and continue to the present day. The dynamics of the sector continued to grow steadily until the mid-1990s, when the number of SF projects began a significant increase, coinciding with a socio-economic context in which volunteering in general and concern for socially vulnerable groups in particular had been almost invisible. In addition, the economic recovery after the 1993 crisis, made it possible to provide public administrations with broader budgetary allocations for social action programs, encouraging the 


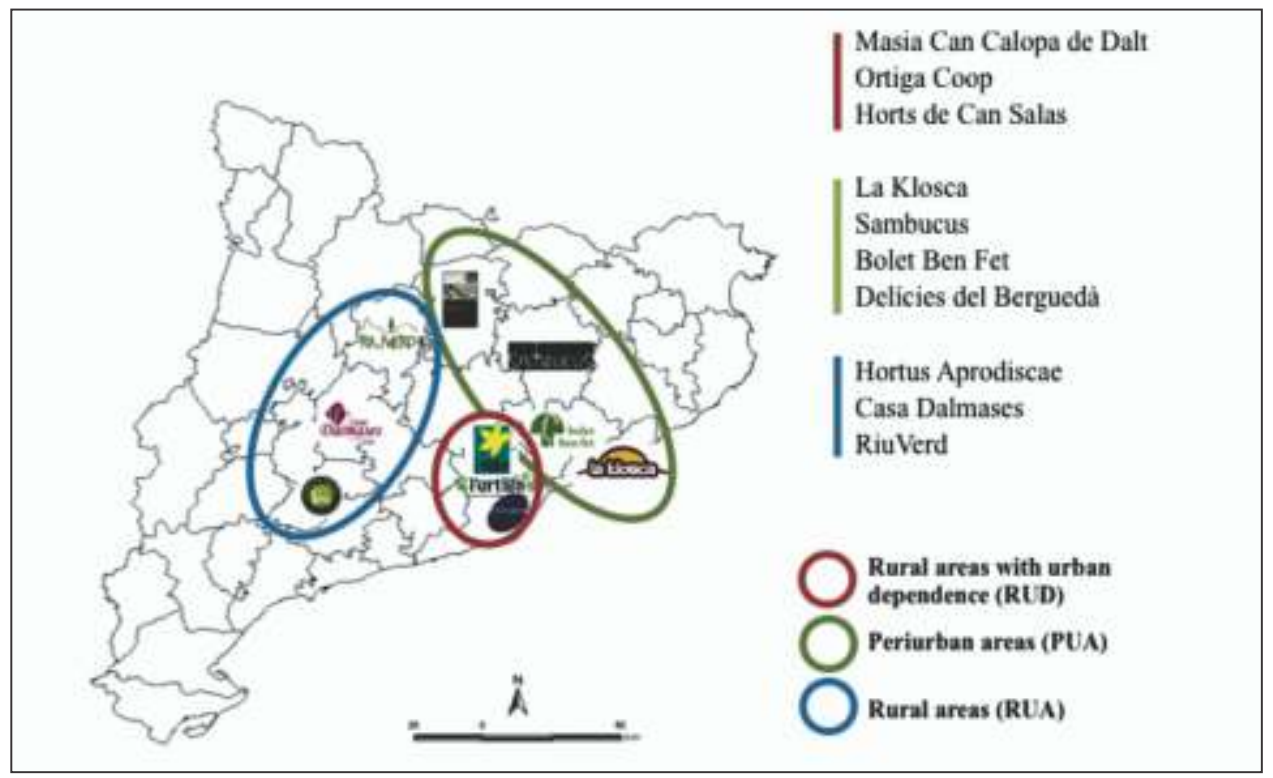

Figure 2. Research Study cases in Catalonia according to rural or urban dependence. Sources: Elaboration from own research data

availability of grants and public subsidies that favoured the consolidation of the phenomenon. As of 2008, a return to social and economic crisis caused the expansion of groups potentially at RSE, which triggered the alarm of TSS organizations. During subsequent years, the creation of projects to address this social emergency has experienced an unprecedented increase, resulting in many civic initiatives to solve the individual and collective needs of the people most affected by the crisis.

Social farming and local sustainable development today: some case studies

In areas where rural-urban migration has been very strong, SF has contributed to a certain territorial balance, avoiding social exclusion in these territories and favouring the creation of social and health care services in rural outlying areas. It has also been a catalyst for economic alternatives, based on a new conception of agriculture, ecological awareness, and local sourcing and also of collaboration with other activities in a given area. In the peri-urban areas, SF has allowed recovery of abandoned land, forest management and a viable economic path for many projects. In our research, we selected 10 case studies in Catalonia: 3 cases in the peri-urban area of Barcelona (PUA), 3 in rural municipalities (MUR) and 4 in rural areas with heavy urban dependency (RUD), shown in (Figure 2).

L'Ortiga Cooperativa (PUA), established in 2010, is structured as a Sociedad Limitada Laboral (SLL) ${ }^{12}$ for the ecological production and commercialization of agricultural products, mainly vegetables, on a 2-ha farm, combined with a social initiative cooperative that provides education and training in collaboration with the social services unit of the city government of Sant Cugat del Vallès to promote the integration of groups living in poverty. This project also presents agriculture-related activities for schools and for adult training sessions (Photo 1), 


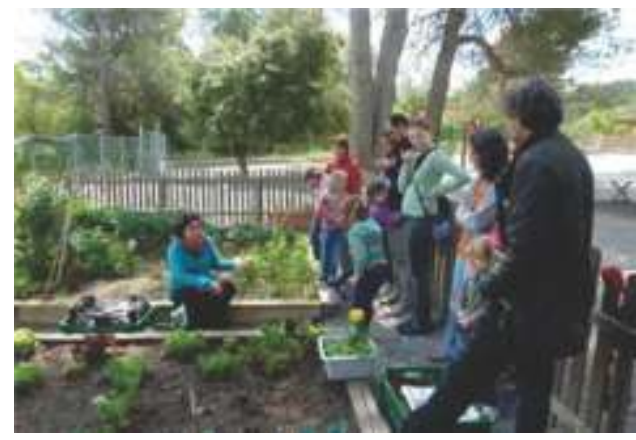

Photo 1. Education program for people at RSE (L'Ortiga)

Source: by the authors of this study

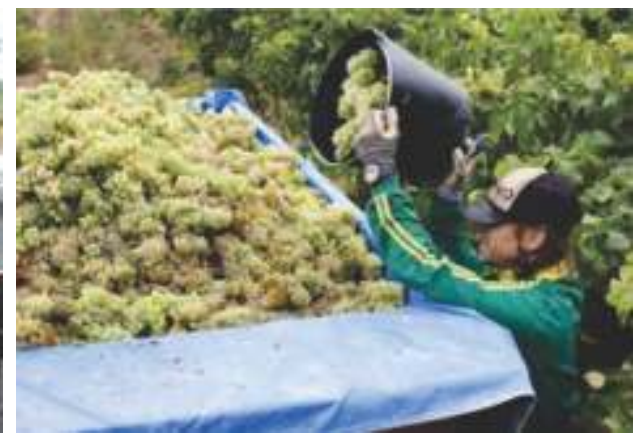

Photo 2. Grape harvesting (L'Olivera) Source: by the authors of this study

and provides farm-to-table baskets for responsible-consumer groups and for private customers via the internet. This initiative won a public contest run by the local government to use the Can Montmany property (Valldoreix) in Collserola Natural Park for 5 years.

RiuVerd (RUA) is a social initiative cooperative created in 2011. Its objective is to integrate and provide social and job training to people in situations of social exclusion as a transition to ordinary employment, especially young people, who are offered personalized training adapted to their needs and circumstances. They also develop other economic activities such as the implementation of a collective healthy-dining room, the cultivation of high-quality organic horticultural products, and their distribution and sale in baskets. They also grow aromatic herbs and provide garden services and other household services.

Aprodisca Ambientals i Ecologics (RUA) is an employment insertion company

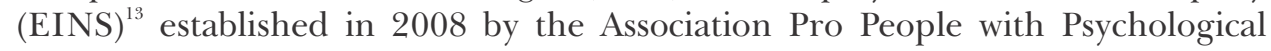
Decline of the Conca de Barberà (APRODISCA) and designated as a special work centre. As a social project in the ecological agro-food sector, it is oriented to the cultivation of vegetables that employs people at RSE. The garden products are used in complementary activities such as the Hortus Aprodiscae project, in which people with intellectual disabilities from APRODISCA prepare baskets of organic products, prepared foods, and processed products (sauces and condiments).

Masia Can Calopa de Dalt (PUA) is a cooperative that manages and works 3 hectares of vineyards on a property owned by the Barcelona City Council and located in Collserola Natural Park. Created in 2010 and related to the L'Olivera Cooperativa project, its objective is to prepare young people from the urban world without prior training for agricultural work activity, providing them with educational support and a group home in a natural environment. They produce mainly wine and olive oil because there are clear methods to follow by people at RSE (Photo 2). It employs 11 young people who do agricultural work on other farms within the Metropolitan Area of Barcelona, in addition to Can Calopa.

Els Horts de Can Salas (PUA) is a project of l'Heura Gardening Centre, SLL, in Terrassa (1994), a non-profit organization for social and labour-market insertion for people with a mental disability and/or mental disorder. Since 2013, they have engaged in ecological production of vegetables on 1 hectare of the Can Salas estate (Terrassa), which will be expanding to 3 hectares because of 


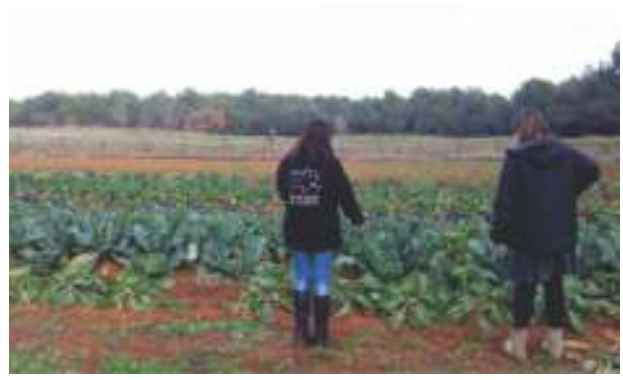

Photo 3. Young people at RSE growing vegetables

Source: by the authors of this study

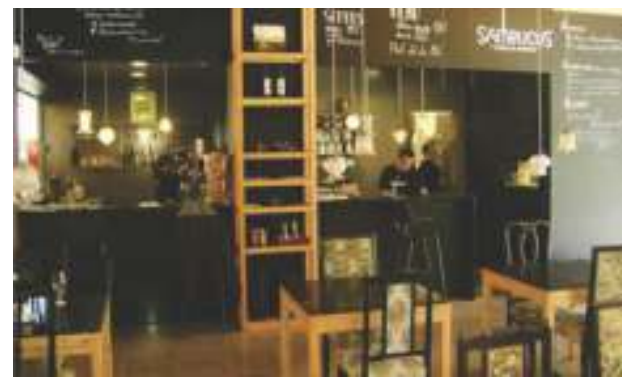

Photo 4. A restaurant manage by people at RSE

Source: by the authors of this study

their economic success (Photo 3). They have a garden centre store and supply "baskets" to consumer groups, make direct sales, and offer catering. They promote short food supply chains and have developed an educational program for schools and training workshops for families.

Sambucus (RUD) is a cooperative in Manlleu (Barcelona), founded in 2010, which aims to empower people at RSE. In collaboration with social services in surrounding municipalities, they maintain an organic garden, run a restaurant in the Municipal Market (Photo 4), manage kitchens for other groups, and provide catering. They also grow aromatic plants using ecological methods (Photo 5), dry them in their own facilities, and market them. This comprehensive project is based on connecting the process, from product origin to final consumer, and controlling the entire production and distribution cycle.

Casa Dalmases Foundation (RUA), created in 2009 to manage the manor house of the same name, has a dual objective of providing opportunities for people with mental disabilities $(\mathrm{CET})^{14}$ to engage in the production of craft beers and opening part of the manor house to the general public for social and cultural events. A shop on the ground floor of Casa Dalmases employs people with disabilities from an occupational centre and sells products from other social entities in the region. It also employs homeless people to participate in the market days of surrounding towns. In 2015, the foundation started producing artisanal chocolate in collaboration with social organizations and producers in Guatemala.

Bolet Ben Fet (RUD) began in 2009 as a collaboration between an entrepreneur and the $\mathrm{TEB}^{15}$ Cooperative Group, an organization dedicated to finding opportunities for people with mental disabilities. The objective is social and labour insertion of people with these disabilities, through a special work centre in an old farmhouse in Sant Antoni de Vilamajor (Vallès Oriental) where they cultivate shitake and maitake mushrooms, using ecological production methods (Photo 6).

La Klosca (RUD), also established in 2009, produces organic eggs on the Sant Miquel de Mata estate owned by the City of Mataró. Created through a social entity, this initiative aims to complete the "social, health and occupational circle of care" for people affected by severe mental disorder with which it works. This entity is a reconversion to SF of nurseries that previously grew aromatic and ornamental plants. Delícies del Berguedà (RUD), a trademark of the Portal Berguedà insertion company founded by Fundació Portal, was created in 2011. 


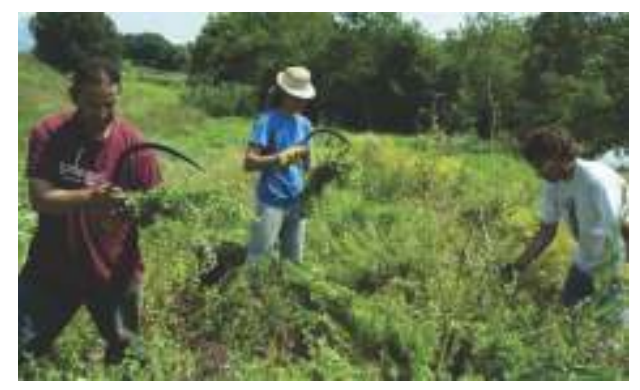

Photo 5. Unemployed young people harvesting health herbs

Source: by the authors of this study

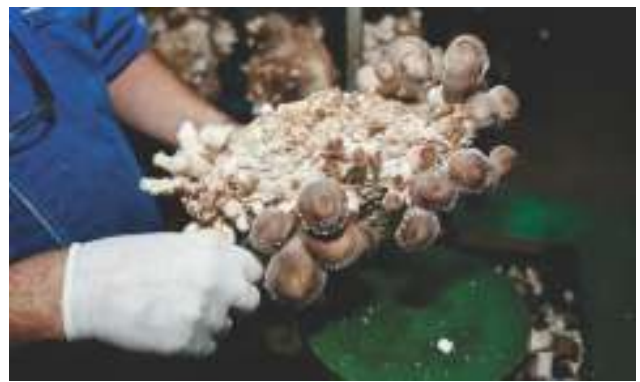

Photo 6. Ecological mushrooms grown by people with mental disabilities

Source: by the authors of this study

This organization helps young people with dual pathology and their families in the region of Berguedà. Its main activity is the production of dairy products such as yoghurts and cheese, using local raw materials from a nearby farm, thus promoting local consumption, synergies between initiatives within the same territory, and sustainable rural development.

It is important to point out that 8 of the 10 entities studied have received or are in the process of qualifying for the official certification for ecological agriculture from the relevant Catalan authority, the "Consell Català de la Producció Agrària Ecològica" (CCPAE) ${ }^{16}$. This allows us to confirm that these SF projects have are committed to ecological agriculture.

\section{Conclusions}

In Europe, expansion of SF has been heterogeneous because of different traditions of social development in Mediterranean countries (Italy, France, Spain, and Portugal), compared to central and northern countries. Specific SF legislation has been passed in Belgium, Italy, and The Netherlands, where there are many projects. In contrast, Portugal and Spain have only a few projects, with the exception of Catalonia, where SF appeared in the 1970s. In 2016, there were more than 150 projects serving people with disabilities through family associations (foundations and cooperatives) with subsidies from the Spanish State and Catalan Government. Nevertheless, since the economic crisis began in 2008, the sector has experienced major growth, expanding to other RSE populations with social and economic concerns. Local authorities and the TSS are taking leadership in this SF expansion.

Most of the SF entities in Catalonia have an ethical and social vocation, based on the principles of equity and social justice, and give priority to people over profit. They offer people the opportunity to have a decent job and/or to receive healing therapies and health services. Nevertheless, SF projects must show social and economic viability to be able to survive. Measuring Social Return on Investment (SROI), defined as the social impact of investing in a project with social service characteristics, focuses on three broad dimensions: economic, social, and environmental impact. The objective of using SROI methodology is to demonstrate how SF projects make a major contribution to society, generating changes in the individuals they work with, in the immediate surroundings, and 
in the broader society. The end result of SROI assessment reflects the multiplication factor of the investment in a given project, showing the return to society of each $1 €$ invested. Among the 10 studied cases in our research, this return ranges from $2.01 €$ in Sambucus to $6.01 €$ in L'Ortiga.

We may conclude that $\mathrm{SF}$ projects in Catalonia have made five main contributions to SRD: (1) Empowerment of socially vulnerable people; (2) Contribution to local development and territorial equity by promoting resilience; (3) Encouraging a social and solidarity economy (SSE) and a cooperative structure for SF entities; (4) Dissemination of innovative social projects and strategies to promote organic agriculture and agro-ecology production and collaborative trade approaches; and (5) Contribution to environmental protection and recovery of agrarian land.

\section{Acknowledgements}

This paper is related to the 2014 ACUP-00029 project financed by "Caixa Foundation" and CSO2012-31979 project fund (Ministry of Economy and Competitiveness of Spain).

\section{Endnotes}

1. SoFar (2008) sofar.unipi.it/

2. Network in SF: fundaciocatalunya-lapedrera.com/ca/content/xarxa-agrosocial

3. Land social provider in France: www.terredeliens.org/

4. Organization to provide land to farmers in Catalonia: www.terrafranca.cat/

5. Soil provider in the U.K.: www.soilassociation.org/the-land-trust/

6. German provider of land: www.accesstoland.eu/-Regionalwert-AG-

7.Italian SF law (18-8-2015): gazzettaufficiale.it/eli/id/2015/09/8/15G00155/sg

8. Réseau Cocagne (2007): www.reseaucocagne.asso.fr/

9. Réseau Astra (2009): www.res-astra.org/

10. L'Olivera Cooperativa was one of the first SF initiatives in Catalonia. This social project originated in Vallbona de les Monges (Lleida) in 1974 and remains active. Its main objective is to offer opportunities for people with mental disabilities in a rural environment to engage in agricultural work related to cultivating vineyards and olive orchards and producing wine and oil. Support services include a group home, a work centre, and health and human services professionals. More information: www.olivera.org

11. La Fageda is a cooperative that was established in 1982 within a Carmelite convent (Olot, Girona) with 15 residents, mainly from a psychiatric residence. In 1985, a residence and occupational therapy facility were established, with a contract to sell milk from a dairy herd of 100 cows to Nestle-Girona. In 1993, the cooperative began production of 50,000 yoghurts weekly for direct sales and to supply large dining rooms. In 1997, a foundation was created and La Fageda expanded its range of dairy products. In 2015, 256 employees (50\% with a diagnosed disability) produced 60 million yoghurts (5\% of the Catalan market), among other products: www.fageda.com/ca

12. In a SLL, at least $51 \%$ of the social capital belongs to the workers, and no 
individual stockholder can hold more than one third of the capital, except a public entity that can hold up to $49 \%$.

13. Public Law 27/2002, dated 20-12-2002, established legislative measures to regulate these entities (empresas de inserción sociolaboral, EINS). DOGC 3793, dated 3/01/2003.

14. Special work centres (Centre especial de treball, or CET) were created by the Catalan government (Generalitat de Catalunya) in 1982, under an agreement between non-profit entities and the government. Economic concessions were made in exchange for the employment of individuals at RSE and for providing the training and therapy they would require.

15. TEB (Taller Escola Barcelona) was established in 1968 by a group of families with children with disabilities and currently includes 7 cooperatives and various special work centres (CETs).

16. More information: www.ccpae.org

\section{References}

Atchoarena, D \& Gasperini, L (eds) 2003, Education for Rural Development. Towards New Policy Responses, FAO/UNESCO, Rome.

Barrachina, M, Cristobal, J \& Tulla, AF 2015, 'Estimating above-ground biomass on mountain meadows and pastures through remote sensing', International Journal of Applied Earth Observation and Geoinformation, vol. 38, pp. 184-192.

Best, S 1989, 'The commodification of reality and the reality of commodification: Jean Baudrillard and post-modernism', Current Perspectives in Social Theory, vol. 19, pp. 23-51.

Dessein, J, Bock, BB \& Krom, MP 2013, 'Investigating the limits of multifunctional agriculture as the dominant frame for Green Care in agriculture in Flanders and the Netherlands', Journal of Rural Studies, vol. 32, pp. 50-59.

Di Iacovo, F \& O'Connor, D (eds) 2009, Supporting Policies for Social Farming in Europe. Progressing Multifunctionality in Responsive Rural Areas, ARISA, Firenze.

Di Iacovo, F, Moruzzo, R, Rossignoli, C \& Scarpellini, P 2014, 'Transition management and social Innovation in rural areas: Lessons from social farming', The Journal of Agricultural Education and Extension, no. 20, pp. 327-247.

Esparcia, J 2000, 'The LEADER Programme and the Rise of Rural Development in Spain', Sociologia Ruralis, vol. 40, no. 2, pp. 200-207.

Exterckoter, RK, Azevedo da Silva, C \& Tulla, AF 2015, 'Family farmers as agents of resilience in the western region of Santa Catarina (Brazil)', Ager, vol. 18, pp. 11538.

Halfacree, K 2007, 'Still surprises in store. Revisiting the ordinary in rural geography', Documents d'Anàlisi Geogràfica, vol. 50, pp. 87-103.

Hassink, J \& Van Dijk, M 2006 (eds), Farming for Health: Green-care Farming across Europe and the United States of America, Springer, Dordrecht.

Idescat 2013, Catalan Statistics Institute: Agrarian farmer's structure 1993-2007, Generalitat de Catalunya, Barcelona.

Idescat 2016, Catalan Statistics Institute: Population Census, Generalitat de Catalunya, Barcelona. 
INE 2016, Spanish Institute of statistics: Active population Survey, Madrid.

Laville, JL 2015, Asociarse para el bien común. Tercer Sector, Economía Social y Economía Solidaria, Editorial Icaria, Barcelona.

Lipsey, RG \& Lancaster, K 1956, 'The General Theory of Second Best', Review of Economic Studies, vol. 24, pp. 11-32.

Myrdal, G 1957, Economic Theory and Under-Developed Regions, Gerald Duckworth \& Co. Ltd, London.

Ohlin, B 1933, Interregional and International Trade, Harvard University Press, Cambridge, MA.

Olsen, E 1971, International Trade, Theory and Regional Income Differences, NorthHolland, Amsterdam.

Pallarès-Barberà, M, Tulla, AF \& Vera, A 2004, 'Spatial loyalty and territorial embeddedness in the multi-sector clustering of the Berguedà in Catalonia (Spain)', Geoforum, vol. 35, no. 5, pp. 635-649.

Pallarès-Blanch, M, Prados, MJ \& Tulla, AF 2014, 'Naturbanization and UrbanRural Dynamics in Spain: case study of New Rural Landscapes in Andalusia and Catalonia', European Countryside, vol. 6, no. 2, pp. 118-160.

Pallarès-Blanch, M, Tulla, AF \& Vera, A 2015, 'Environmental capital and women's entrepreneurship: A sustainable local development approach', Carpathian Journal of earth and Environmental Sciences, vol. 10, no 3, pp. 133-146.

Peet, R \& Hartwick, E 1999, Theories of development, The Guilford Press, New York.

Perkins, HC 2006, 'Commodification: re-resourcing rural areas', in P Cloke, T Marsden \& P Mooney (eds), Handbook of Rural Studies, Sage, London, pp. 243-57.

Ploeg, JD van, Renting, H, Brunori, G, Knickel, K, Mannion, J, Marsden, T, De Roest, K, Sevilla-Guzman, E \& Ventura, F 2000, 'Rural development: from practices and policies towards theory', Sociologia Ruralis, vol. 40, no. 4, pp. 391408.

Potter, C 2004, 'Multifunctionality as an agricultural and rural policy concept', in F Brouwer (ed), Sustaining Agriculture and the Rural Environment, Edward Elgar, Cheltenham, pp. 15-35.

Sempik, J, Hine, R \& Wilcox, D (eds) 2010, 'Green Care: A Conceptual Framework. A Report of the Working Group on the Health Benefits of Green Care', COST 866, Green Care in Agriculture, Centre for Child and Family Research, Loughborough University, Loughborough.

Tulla, AF, Pallarès-Barberà, M \& Vera, A 2009, 'Naturbanization and local development in the mountain areas of the Catalan Pyrenees', in MJ Prados (ed) Naturbanization: New identities and processes for rural-natural areas, Taylor \& Francis Group, London, pp. 75-92.

Tulla, AF, Vera, A, Badia, A, Guirado, C \& Valldeperas, N 2014, 'Rural and Regional Development Policies in Europe: Social Farming in the Common Strategic Framework (Horizon 2020)', Journal of Urban and Regional Analysis, vol. 6, no. 1, pp. 35-51.

United Nations General Assembly 1987, Report of the world commission on environment and development: Our common future, UNGA, Development and International Cooperation: Environment, Oslo, Norway.

Vera, A, Badia, A \& Tulla, AF 2011, 'Desarrollo local en el Pirineo Catalán: impulso económico y uso sostenible del territorio', Finisterra, vol. 6, no. 92, pp. 9-27. 